\title{
International Parity Relations and Economic Shock: Evidence from Swiss Franc Unpegging
}

\author{
Hoje Jo ${ }^{1}$, Julian Dixon ${ }^{1}$, Toshi Masubuchi ${ }^{1}$, Manali $\operatorname{Parmar}^{1} \&$ Stuti Rastogi ${ }^{1}$ \\ ${ }^{1}$ Santa Clara University, Santa Clara, USA \\ Correspondence: Hoje Jo, Santa Clara University, Santa Clara, CA 95053, USA.
}

Received: April 28, 2016

Accepted: May 19, 2016

Online Published: June 25, 2016

doi:10.5430/ijfr.v7n4p1

URL: http://dx.doi.org/10.5430/ijfr.v7n4p1

\begin{abstract}
In this paper, we examine the association between the macroeconomic variables - interest and inflation rate, and the expected spot rate of Swiss franc against Euro around the abandonment of the ceiling on the Swiss franc by the Swiss National Bank (SNB), January 15, 2015, using the two international parity relationships, International Fisher effect (IFE) and Purchase Power Parity (PPP). We use the regression analysis to examine the significance of change in daily interest rates and monthly inflation rates on the change in actual daily spot rates. While our empirical results indicate no significant statistical relationship between the two inputs before unpeg period, our additional analysis examining both the magnitude and directional deviation of the actual spot rate compared to the spot rate for both unpeg and peg period predicted using the two parity relations suggest that spot rates predicted based on the IFE relations, in general, is relatively better in predicting the daily spot rate compared to that of the PPP relations. Although both parity relations are not perfect models for predicting daily exchange rates, they can be used as a framework to guide financiers to gain additional insight regarding the short-term directional trend of the spot rate.
\end{abstract}

Keywords: international fisher effect, purchasing power parity, Swiss franc unpegging

\section{Introduction}

Since the introduction of the peg, the Swiss National Bank (SNB) sold a total of approximately 500 billion Swiss franc to buy foreign currencies, which now sits on its balance sheet. The decision by the SNB was largely successful in stabilizing the franc against the euro and in turn Switzerland's exporting sector. The Swiss franc has been a very popular place to park cash. Amid the euro zone debt crisis, demand for the Swiss franc surged, pushing its value up sharply (Phillips, 2015). Recently, with the United States economy recovering strongly post financial crisis, the dollar has strengthened. In addition, with the impending crisis in Greece and the Eurozone slipping into deflation owing to lack of demand euro witnessed a sharp depreciation. Along with the US, UK and Japanese economy having successfully implemented the extensive bond buying program, the European Central Bank (ECB) announced the launch of a large scale government bond purchase program, Quantitative Easing, which could possibly increase the supply of euros in the economy and thus lead to a further depreciation in euros (See Blackstone and Maclucas (January 20, $2015 \quad$ Wall $\quad$ Street $\quad$ Journal) from http://www.wsj.com/articles/switzerland-scraps-currency-cap-1421320531?mg=id-wsj). The economic conditions in both Eurozone and US put financial pressure on the SNB to act in order to maintain its currency and economy's competitiveness. Ultimately, on January 15, 2015, the central bank based in Zurich, SNB, announced the removal of the peg.

The move by SNB to unpeg the Swiss franc created a financial turmoil in the global economy and the franc shot up by $40 \%$ within minutes of removing the peg and finally settled at around $20 \%$ appreciation against Euros. As a result, hedge funds and investors incurred huge losses on their positions. This unexpected move by SNB poses the question as to where is the franc headed in the short term and would SNB be able to achieve its objective of taming the appreciation in the Franc relative to the Euro. The objective to peg was to prevent the franc from appreciating and protecting the country's exports. Now with the peg removed, it is of great concern for all market participants, investors and financial managers, as to how the Swiss franc will move in the short-term.

The main objective of this study is to examine whether the two international parity relations, international Fisher effect (IFE) and purchasing power parity (PPP), are viable frameworks that can be used to predict the daily exchange rates in the short-term. Surprisingly, there is a dearth of academic literature on the parity relations' predictability on 
the short-term spot rates, although decades of exchange rate studies have discovered many well-known empirical puzzles, in essence failing to connect floating exchange rates to their theoretical macroeconomic determinants, or fundamentals (Aliber, 1973; Chen and Tsang, 2013). Frenkel and Rose (1995) offer a comprehensive summary of the various difficulties confronting the empirical exchange rate literature. Sarno (2005) and Rogoff and Stavrakeva (2008) present more recent surveys. Because the measurement of market expectations is quite difficult, if not impossible, additional assumptions, such as a linear driving process for the fundamentals, are typically imposed in order to relate the exchange rate to its currently observable fundamentals (Mark, 1995; Engle and West, 2005; Chen and Tsang, 2013 among many others). While Hakkio (1992) argues that the short-term different political and economic shocks could drive the movement of exchange rates, we further extend the idea and maintain that short-term exchange rates can be looked by using the parity relations to understand the probable directional changes of exchange rates influenced by the political and economic shock that impact the movement of the exchange rate of interest. In addition, we scrutinize the implications of the actions taken by the SNB and ECB. The competing initiatives of the SNB and ECB and the actions they take will have profound short-term effects on key macroeconomic variables such as interest and inflation rate, and, in turn, the valuation of the franc. Under the IFE and PPP frameworks, we provide additional insight as to how changes in macroeconomic variables account for short-term movement of the Swiss franc relative to the euro.

The Swiss National Bank and the European Central Bank (ECB) have a mandate to control price levels using monetary policy. Their decisions impact the country's prevailing interest and inflation rates, which in turn impact the movement of the Swiss franc and Euro. Various market participants like hedge funds, multi-national companies, central banks and regulators who closely monitor the movement of these key macroeconomic variables are directly impacted by the fluctuation of the these currencies. Therefore, the ability to predict the short-term movement of a currency with maximum certainty is indispensable for all financial market participants.

Our initial results indicate weak (no) significant statistical relationship between the interest (inflation) rate, and the expected spot rate of Swiss franc around the Swiss franc unpegging. Our additional analysis examining both the magnitude and directional deviation of the actual spot rate compared to the spot rate predicted using the two parity relations, however, suggest that IFE relations performs better in predicting the daily spot rate than the PPP relations. We also find that although both parity relations are not perfect models for predicting daily exchange rates, they can be used as a framework to guide financiers to gain additional insight regarding the short-term trend of the spot rate. Our results further provide additional evidence supporting the idea that in the short-term different political and economic shocks will drive the movement of exchange rate, as suggested by Hakkio (1992) and others.

\section{Swiss Economy, Swiss Franc Pegging, and Unpegging}

The Swiss Economy is one of the most affluent nations across the world with a well-defined manufacturing industry and a highly developed service sector. Over the years, the country has been able to specialize in a highly skilled labor force at a low unemployment rate of around 3.4\% (Dec 14, 2014). According to the world economic forum - Global Competitiveness Report 2014-2015, Switzerland ranks $1^{\text {st }}$ for the sixth consecutive year owing to its business sophistication, highly educated talent pool, innovation, efficient labor market and world class infrastructure, followed by Singapore and United States (http://reports.weforum.org/global-competitiveness-report-2014-2015/report-highlights/\#map). The economy has grown at an average annual rate of $1.31 \%$ from 2008-2014 (http://www.statista.com/statistics/263611/gross-domestic-product-gdp-growth-in-switzerland/) (see Figure 1).

During the period 2008-2014 there was inconsistent economic growth largely due to the European sovereign debt crisis beginning 2008, which led investors to park their assets in Switzerland, the safe haven. Due to the increasing demand for the Swiss currency, the franc soared 35\% against the euro from 2009 to September 2011 (http://www.futuresmag.com/2011/12/31/exploiting-franc-peg). The rapid appreciation of the Swiss franc became a serious concern for an economy heavily dependent on its exporting sector in industries such as chemical and medicinal products, machinery, instruments and watches (http://ec.europa.eu/trade/policy/countries-and-regions/countries/switzerland/). Ultimately, to prevent further long-term damage to its export and tourism industry, on September 06, 2011, Swiss National Bank (SNB) announced the decision to peg its currency at 1.20 Swiss Franc per Euro.

The franc overvaluation has been controlled since the introduction of the peg. To stabilize the franc relative to the euro, the SNB bought large amounts of euros, which is now sitting on its balance sheet. With the depreciating euro, SNB found it hard to retain its competitive advantage. The fact that SNB would continuously require Francs to buy Euros to maintain the peg exposed the Swiss economy to a huge exchange rate risk. Secondly, the stimulus plan by 
ECB was focused to support the Europe's fragile economy. This move would in turn cause the euro to depreciate even further, placing additional financial pressure on the SNB. Additionally, with the United States economy recovering strongly, the euro continued to weaken, making it difficult for the SNB to continue intervening in the currency market. Ultimately, on January 15, 2015, the central bank based in Zurich announced the removal of the peg.

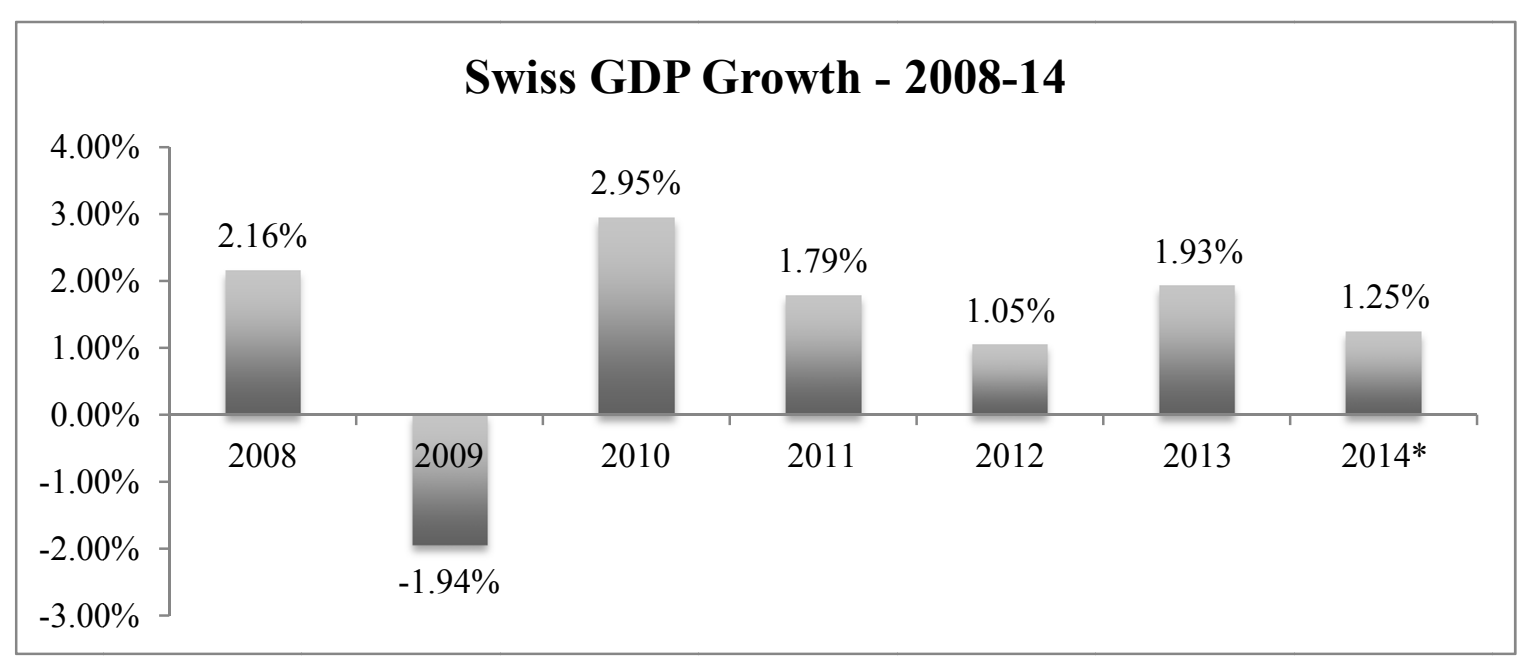

Figure 1. Swiss GDP growth rate during 2008 and 2014

\section{Literature Review and Hypothesis Formation}

International parity relationships consider the most important macroeconomic variables that are used to determine the state of the economy and facilitate a comparison across countries. Interest rates and inflation rates are two of the competing policies that central banks take interest in achieving. They not only determine the strength of the economy but also signal the direction in which the economy is headed. US economy witnessed its worst recessions owing to rising interest rate and inflation. A rise in the asset prices and stock market do not signal that the economy is buoyant and is on a growth trajectory, since what actually determines the living standard of the people is the change in inflation rate. Excluding the cost of gas and the general rise in food prices gives a poor estimate of the real inflation in an economy. Hence when US witnessed an asset boom and stock market boom, it assumes that the economy is growing and subsequently the standard of living. However, this is contrary to the macroeconomic fundamentals since inflation is not factored into to consider the general health of the economy.

There has been a debate regarding the possibility and the extent to which international parity relations can predict exchange rate movements. Specifically, there have been a number of studies conducted that support the use of both the IFE and PPP relations to predict the long-term direction of the spot price for a given currency. Hakkio (1992) suggests that PPP is a useful guide in predicting the exchange rate in the long run, but to a lesser extent in the short run. In the short run, the study suggests that PPP forces are weak in that different political and economic events will move the exchange rates independent of what parity suggest. Additionally, the study suggests that only when the deviation from parity is unusually large is there a tendency for the currency to revert back towards parity in the short run.

Hauner, Lee and Takizwa (2011) maintain that inflation rates are both robust and important factors for market forecasters forming exchange rate expectations. They state that under a crawling peg regime, the PPP effect is stronger, because market participants will trade based on the expectation that the exchange rate will revert back to the rate at which the currency is pegged at. Kravis and Lipsey (1978) and Frenkel (1981) further suggest that PPP explains poorly the behavior of exchange rates. Adler and Lehman (1983) find that deviations from PPP follow a random walk, without providing systematic pattern to revert to PPP. Abuaf and Jorion (1990) suggest that while deviations from PPP tend to be substantial in the short run, deviations from PPP appear to take about three years to be reduced in half and PPP tends to hold in the long run. Chen and Tsang (2013) conduct a study using the Nelson-Siegel (1987) model analyzing the viability IFE relations by looking whether the interest differential between two countries drive expected appreciation/depreciation of the home currency. Unlike the study conducted by Mark 
(1995) that produced dismal results, especially in the short-term, Chen and Tsang (2013) conclude that the difference between two countries' yield curve can predict exchange rate movements and explain excess currency returns one month to two years ahead.

Having established the importance of these two macroeconomic variables, we examine the extent to which both interest rate and inflation impact currency exchange rates of a given country through the IFE and PPP relations can predict the short-term exchange rate movements. We note that our approach is consistent with previous research using the relative yield spreads to predict future spot exchange rate, such as Frenkel $(1979,1981)$ and hypothesize the following.

Hypothesis 1: To the extent that the parity relations provide consistent directional guidance of future short-term spot rates, current spot prices can be used to predict the directional change of short-term daily exchange rate of the Swiss franc.

\section{Data and Methodology}

To analyze and better understand the short-term movement of the currency (CHF/EUR), the spot rate (CHF/EUR), Libor rate in Switzerland and Eurozone and inflation in Switzerland and Eurozone data was extracted using Bloomberg terminal and applied to the two international parity relationships - International Fisher effect and Purchasing Power Parity.

International Fisher effect (IFE) links the interest rates of home nation and foreign nation with their exchange rates so both the markets are in equilibrium and no arbitrage opportunities exist. Under this condition, the interest rate differential is equal to the forward and spot rate differential (interest rate parity) and the interest rate differential can be used to predict expected future spot rate (international Fisher effect). To the extent that forward rate is a unbiased predictor of the expected future spot rate, interest rate parity (IRP) can be equated to IFE to predict the expected future spot rate of $\mathrm{E}(\mathrm{S})$.

$$
\frac{\underline{i}_{\underline{h}}-\underline{i}_{f}}{1+i_{\mathrm{f}}}=\frac{F-S}{S}=\frac{E(S)-S}{S}
$$

Where, $\mathrm{i}_{\mathrm{h}}=$ Nominal interest rate in home nation; $\mathrm{i}_{\mathrm{f}}=$ Nominal interest rate in foreign nation; $\mathrm{F}=$ Forward exchange rate (CHF/EUR); $\mathrm{S}=$ Spot exchange rate (CHF/EUR); and $\mathrm{E}(\mathrm{S})=$ Expected future, i.e., the next day, spot price. To predict the expected future spot rate for next day, we assume that forward is the unbiased predictor of expected future spot.

Purchasing Power Parity (PPP) suggests that the exchange rate between the currencies of two countries should be equal to the ratio of the countries' price levels. The exchange rate between two countries should be in such a way that an identical good in two different countries are priced has the same price when expressed in the same currency.

$$
\frac{\mathrm{I}_{\underline{h}}-\mathrm{I}_{\underline{f}}}{1+\mathrm{I}_{\mathrm{f}}}=\frac{\mathrm{E}(\mathrm{S})-\mathrm{S}}{\mathrm{S}}
$$

Where, $\mathrm{I}_{\mathrm{h}}=$ Inflation rate in home nation; $\mathrm{I}_{\mathrm{f}}$ Inflation rate in foreign nation; and $\mathrm{E}(\mathrm{S})=$ Expected spot exchange rate (CHF/EUR). Based on the IFE relationship, the difference in interest rates between two countries will dictate the movement of the spot rate. Similarly for PPP relations, nations with lower inflation rates will tend to find their currencies appreciating against the currencies of nations with higher inflation rates.

To better understand the viability of the parity relations to predict short-term spot rates, we first examine, based on historical data, whether daily interest rate and monthly inflation rate differential between two countries really drive the movement of daily spot rates as the parity relations suggest using three different regression analyses as listed below, following Madura (2014).

$$
\begin{gathered}
\frac{E(S)-S}{S}=\alpha+\beta_{1}\left(i_{h}-i_{f}\right)+e \\
\frac{E(S)-S}{S}=\alpha+\beta_{2}\left(I_{h}-I_{f}\right)+\varepsilon \\
\frac{E(S)-S}{S}=\alpha+\beta_{1}\left(i_{h}-i_{f}\right)+\beta_{2}\left(I_{h}-I_{f}\right)+\mu
\end{gathered}
$$


We use the approximation of interest rate differential $\left(i_{h}-i_{f}\right)$ and inflation rate differential $\left(\mathrm{I}_{h}-\mathrm{I}_{\mathrm{f}}\right)$ by taking the simple difference instead of the exact form following Madura (2014) and Eun and Resnick (2015) for easier computation. When we use the exact form of interest rate differential $\left(\mathrm{i}_{\mathrm{h}}-\mathrm{i}_{\mathrm{f}}\right) /\left(1+\mathrm{i}_{\mathrm{f}}\right)$ and inflation rate differential $\left(\mathrm{I}_{\mathrm{h}}-\right.$ $\left.\mathrm{I}_{\mathrm{f}}\right) /\left(1+\mathrm{I}_{\mathrm{f}}\right)$, our untabulated results remain qualitatively the same with our estimation with approximation. While we admit that there exists incompatibility due to daily interest rate and monthly inflation rate, we consider the bias is minimal mainly because both inflation rates in Switzerland and Euro zone are currently extremely low close to zero (see Table 1).

In fact, due to deflation in euro zone, Table 1 shows both inflation rates in Switzerland and euro zone are slight negative numbers ranging from -0.4 to -0.6 percent, respectively. Negative inflation rate means deflation. In addition, both Swiss LIBOR rates and Euro LIBOR rates are negative. A central bank wishing to boost money supply may also be forced to reduce its discount rate to below zero as a way of persuading commercial banks to borrow more funds. For real interest rates, this can occur when the inflation rates are higher than nominal interest rates. See the following Fisher (1930) effect;

$$
1+\mathrm{i}_{\mathrm{N}}=\left(1+\mathrm{i}_{\mathrm{R}}\right) *(1+\mathrm{I})
$$

Where iN stands for nominal interest rate, iR represents real interest rate, and I notes for inflation rate. Thus, if inflation rates are higher than nominal interest rates, real interest rate can be negative.

Thus we performed a comparative study observing the deviation, both the magnitude and direction, of the actual spot price from the predicted spot price based on the parity relations. In our analysis, the home currency is taken to be that of Switzerland while the foreign currency is that of the Eurozone.

\section{Results}

As stated above, two key macroeconomic variables of concern is short-term daily interest rate (Libor rate) and monthly inflation rate both extracted from Bloomberg terminal. Figure 2 shows a plot of the daily Swiss and Eurozone Libor rate during the period from February 24, 2014 to February 24, 2015. Based on this Figure 2, there are two key observations. First, the Euro Libor rate has been trending down for the past year. Second, there was no change in Swiss Libor rate until the SNB announced its decision to unpeg the Swiss franc against the euro currency on January $15^{\text {th }}, 2015$.

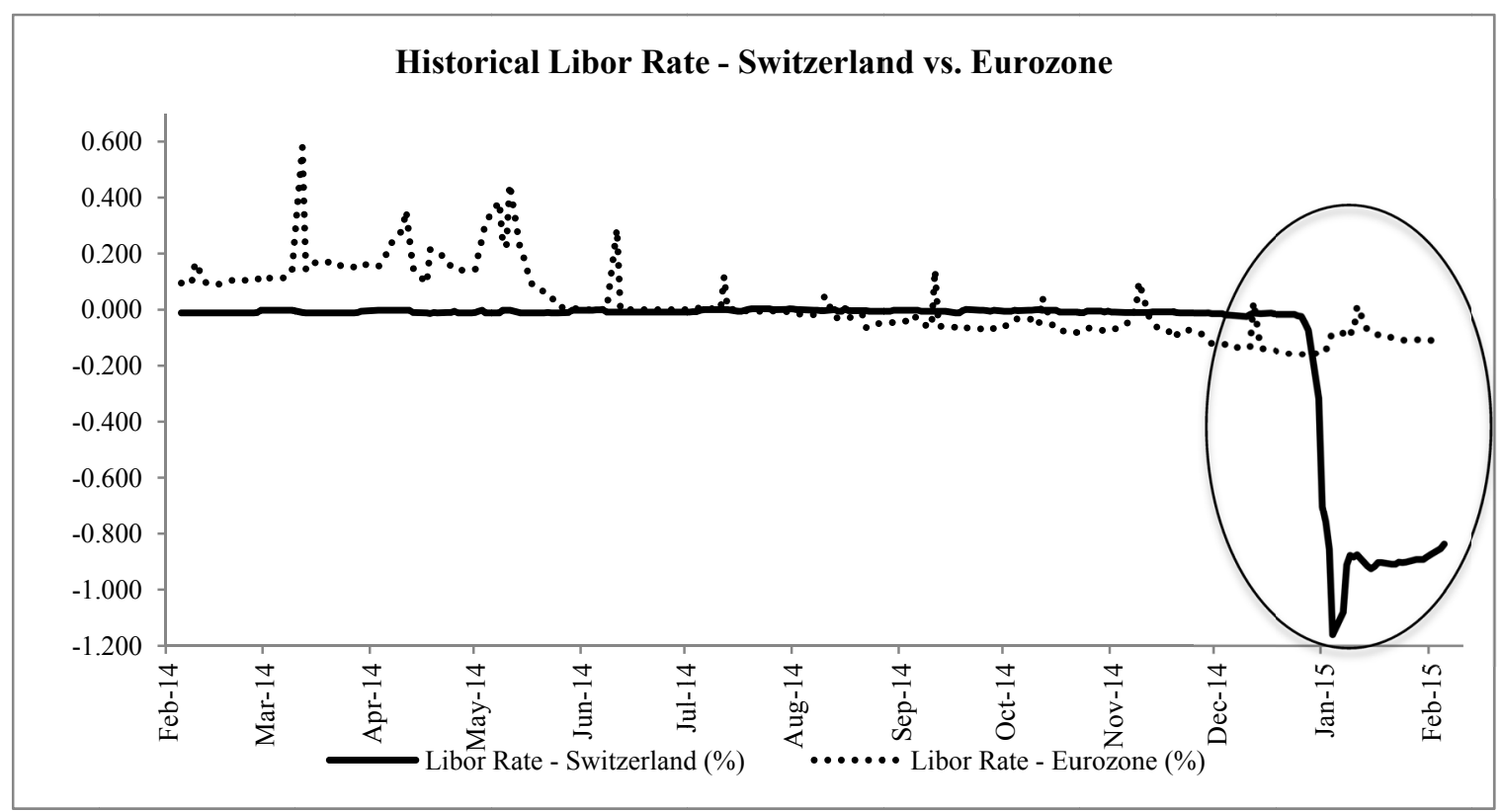

Figure 2. Plot of Switzerland and Eurozone Libor rate (2/24/2014 - 2/24/2015)

Figure 3 shows a plot of the monthly Swiss and Euro inflation rate for the same time period. The main observation based on this graph is that the inflation rate of both Switzerland and the Eurozone has been trending downward, explaining the concerns of both countries looking to monetary policy to stimulate their respective economies. In our 
analysis, based on the two international parity relations, the trends seen in both Figures 2 and 3 are taken to be the main drivers of the changes in daily spot rates.

Figure 4 plots the movement of three different spot rates: the actual, the predicted based on the IFE relations, and the predicted based on the PPP relation and Table 1 illustrates for the period 1/1/2015 to 2/24/2015 how we arrived at the numbers plotted in Figure 4. Due to the drastic drop in the value of the euro, Figure 4 has been dissected into Figures 5 Panels A and B to show movement of the three different spot rates before and after the SNB's decision to unpeg the Swiss franc against the euro currency.

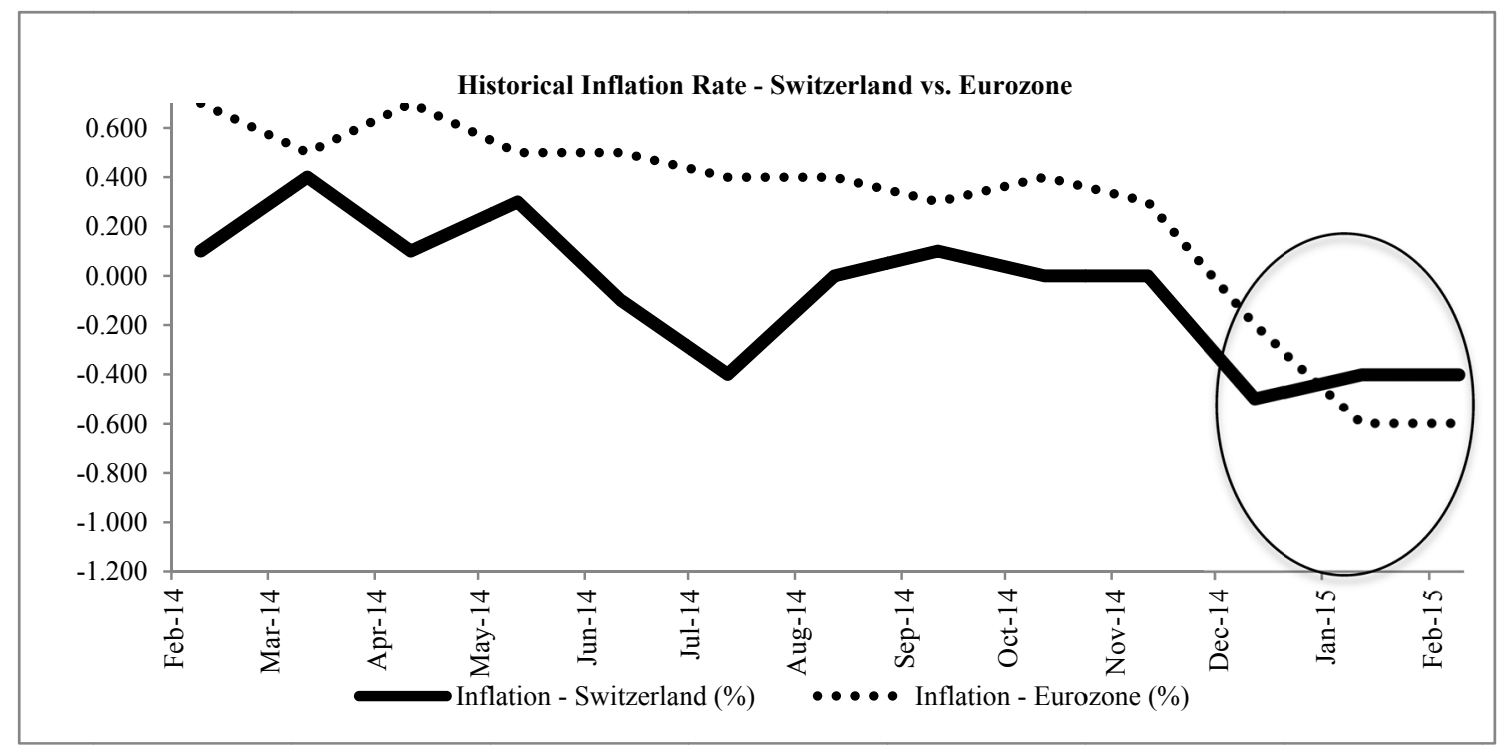

Figure 3. Plot of Switzerland and Eurozone inflation rate (2/24/2014 - 2/24/2015)

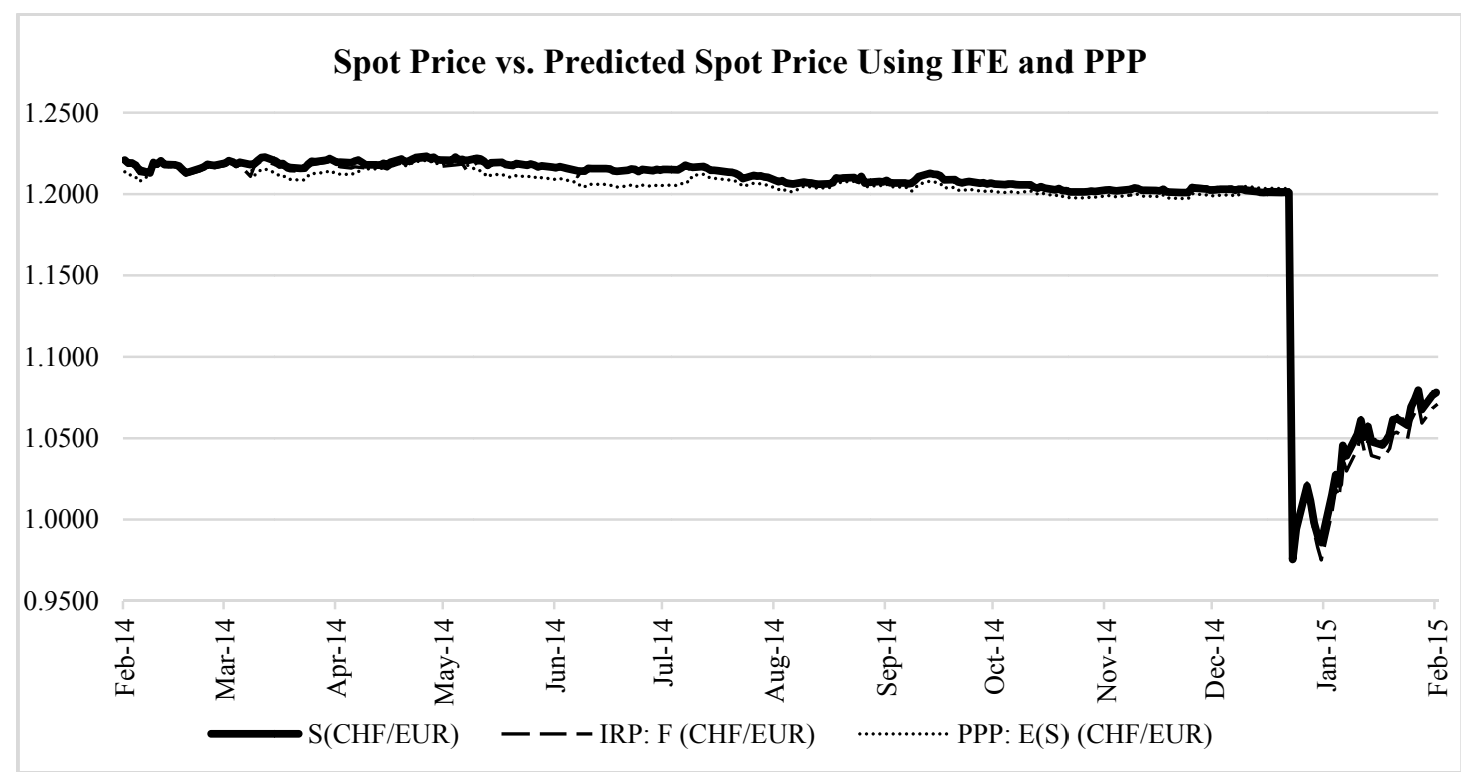

Figure 4. Actual spot price plotted against predicted daily spot prices 
Table 1. Actual Spot rate and Predicted Rates based on IFE and PPP

\begin{tabular}{|c|c|c|c|c|c|c|c|}
\hline Date & $\begin{array}{l}\text { Actual Spot } \\
\text { Rate } \\
\text { (CHF/Euro) }\end{array}$ & $\begin{array}{c}\text { Swiss } \\
\text { Libor } \\
\text { Rate }(\%)\end{array}$ & $\begin{array}{c}\text { Euro } \\
\text { Libor } \\
\text { Rate }(\%)\end{array}$ & $\begin{array}{c}\text { Spot Rate } \\
\text { Based on IFE } \\
\text { (CHF/Euro) }\end{array}$ & $\begin{array}{c}\text { Swiss } \\
\text { Inflation } \\
\text { Rate }(\%)\end{array}$ & $\begin{array}{c}\text { Euro } \\
\text { Inflation } \\
\text { Rate }(\%)\end{array}$ & $\begin{array}{c}\text { Spot Rate } \\
\text { Based on PPP } \\
(\mathrm{CHF} / \text { Euro })\end{array}$ \\
\hline $2 / 24 / 15$ & 1.078 & $-0.838 \%$ & $-0.119 \%$ & 1.070 & $-0.400 \%$ & $-0.600 \%$ & 1.080 \\
\hline $2 / 23 / 15$ & 1.077 & $-0.854 \%$ & $-0.114 \%$ & 1.069 & $-0.400 \%$ & $-0.600 \%$ & 1.079 \\
\hline $2 / 20 / 15$ & 1.068 & $-0.876 \%$ & $-0.106 \%$ & 1.060 & $-0.400 \%$ & $-0.600 \%$ & 1.070 \\
\hline $2 / 19 / 15$ & 1.079 & $-0.884 \%$ & $-0.103 \%$ & 1.071 & $-0.400 \%$ & $-0.600 \%$ & 1.082 \\
\hline $2 / 18 / 15$ & 1.074 & $-0.893 \%$ & $-0.103 \%$ & 1.066 & $-0.400 \%$ & $-0.600 \%$ & 1.076 \\
\hline $2 / 17 / 15$ & 1.069 & $-0.893 \%$ & $-0.106 \%$ & 1.061 & $-0.400 \%$ & $-0.600 \%$ & 1.072 \\
\hline $2 / 16 / 15$ & 1.058 & $-0.893 \%$ & $-0.104 \%$ & 1.050 & $-0.400 \%$ & $-0.600 \%$ & 1.060 \\
\hline $2 / 13 / 15$ & 1.062 & $-0.902 \%$ & $-0.107 \%$ & 1.054 & $-0.400 \%$ & $-0.600 \%$ & 1.064 \\
\hline $2 / 12 / 15$ & 1.061 & $-0.904 \%$ & $-0.106 \%$ & 1.053 & $-0.400 \%$ & $-0.600 \%$ & 1.064 \\
\hline $2 / 11 / 15$ & 1.052 & $-0.902 \%$ & $-0.100 \%$ & 1.044 & $-0.400 \%$ & $-0.600 \%$ & 1.054 \\
\hline $2 / 10 / 15$ & 1.049 & $-0.910 \%$ & $-0.100 \%$ & 1.040 & $-0.400 \%$ & $-0.600 \%$ & 1.051 \\
\hline $2 / 9 / 15$ & 1.046 & $-0.910 \%$ & $-0.096 \%$ & 1.037 & $-0.400 \%$ & $-0.600 \%$ & 1.048 \\
\hline $2 / 6 / 15$ & 1.048 & $-0.904 \%$ & $-0.096 \%$ & 1.040 & $-0.400 \%$ & $-0.600 \%$ & 1.050 \\
\hline $2 / 5 / 15$ & 1.057 & $-0.904 \%$ & $-0.087 \%$ & 1.049 & $-0.400 \%$ & $-0.600 \%$ & 1.059 \\
\hline $2 / 4 / 15$ & 1.051 & $-0.918 \%$ & $-0.080 \%$ & 1.042 & $-0.400 \%$ & $-0.600 \%$ & 1.053 \\
\hline $2 / 3 / 15$ & 1.061 & $-0.926 \%$ & $-0.074 \%$ & 1.052 & $-0.400 \%$ & $-0.600 \%$ & 1.063 \\
\hline $2 / 2 / 15$ & 1.052 & $-0.916 \%$ & $-0.072 \%$ & 1.043 & $-0.400 \%$ & $-0.600 \%$ & 1.054 \\
\hline $1 / 30 / 15$ & 1.039 & $-0.876 \%$ & $0.016 \%$ & 1.030 & $-0.400 \%$ & $-0.600 \%$ & 1.041 \\
\hline $1 / 29 / 15$ & 1.046 & $-0.884 \%$ & $-0.081 \%$ & 1.037 & $-0.400 \%$ & $-0.600 \%$ & 1.048 \\
\hline $1 / 28 / 15$ & 1.022 & $-0.878 \%$ & $-0.078 \%$ & 1.014 & $-0.400 \%$ & $-0.600 \%$ & 1.024 \\
\hline $1 / 27 / 15$ & 1.028 & $-0.912 \%$ & $-0.061 \%$ & 1.019 & $-0.400 \%$ & $-0.600 \%$ & 1.030 \\
\hline $1 / 26 / 15$ & 1.015 & $-1.080 \%$ & $-0.081 \%$ & 1.005 & $-0.400 \%$ & $-0.600 \%$ & 1.017 \\
\hline $1 / 23 / 15$ & 0.986 & $-1.160 \%$ & $-0.081 \%$ & 0.975 & $-0.400 \%$ & $-0.600 \%$ & 0.988 \\
\hline $1 / 22 / 15$ & 0.990 & $-0.856 \%$ & $-0.104 \%$ & 0.983 & $-0.400 \%$ & $-0.600 \%$ & 0.992 \\
\hline $1 / 21 / 15$ & 0.998 & $-0.758 \%$ & $-0.145 \%$ & 0.992 & $-0.400 \%$ & $-0.600 \%$ & 1.000 \\
\hline $1 / 20 / 15$ & 1.012 & $-0.702 \%$ & $-0.156 \%$ & 1.006 & $-0.400 \%$ & $-0.600 \%$ & 1.014 \\
\hline $1 / 19 / 15$ & 1.021 & $-0.316 \%$ & $-0.155 \%$ & 1.019 & $-0.400 \%$ & $-0.600 \%$ & 1.023 \\
\hline $1 / 16 / 15$ & 0.994 & $-0.071 \%$ & $-0.155 \%$ & 0.995 & $-0.400 \%$ & $-0.600 \%$ & 0.996 \\
\hline $1 / 15 / 15$ & 0.976 & $-0.045 \%$ & $-0.154 \%$ & 0.977 & $-0.400 \%$ & $-0.600 \%$ & 0.978 \\
\hline $1 / 14 / 15$ & 1.201 & $-0.022 \%$ & $-0.159 \%$ & 1.203 & $-0.400 \%$ & $-0.600 \%$ & 1.203 \\
\hline $1 / 13 / 15$ & 1.201 & $-0.020 \%$ & $-0.157 \%$ & 1.203 & $-0.400 \%$ & $-0.600 \%$ & 1.203 \\
\hline $1 / 12 / 15$ & 1.201 & $-0.015 \%$ & $-0.156 \%$ & 1.203 & $-0.400 \%$ & $-0.600 \%$ & 1.203 \\
\hline $1 / 9 / 15$ & 1.201 & $-0.015 \%$ & $-0.156 \%$ & 1.203 & $-0.400 \%$ & $-0.600 \%$ & 1.204 \\
\hline $1 / 8 / 15$ & 1.201 & $-0.015 \%$ & $-0.152 \%$ & 1.203 & $-0.400 \%$ & $-0.600 \%$ & 1.203 \\
\hline $1 / 7 / 15$ & 1.201 & $-0.015 \%$ & $-0.147 \%$ & 1.203 & $-0.400 \%$ & $-0.600 \%$ & 1.203 \\
\hline $1 / 6 / 15$ & 1.201 & $-0.015 \%$ & $-0.144 \%$ & 1.203 & $-0.400 \%$ & $-0.600 \%$ & 1.204 \\
\hline $1 / 5 / 15$ & 1.202 & $-0.012 \%$ & $-0.141 \%$ & 1.203 & $-0.400 \%$ & $-0.600 \%$ & 1.204 \\
\hline $1 / 2 / 15$ & 1.202 & $-0.014 \%$ & $-0.139 \%$ & 1.204 & $-0.400 \%$ & $-0.600 \%$ & 1.205 \\
\hline
\end{tabular}

Note: The daily interest rate and monthly inflation rate were taken for Switzerland and Eurozone. These rates were taken as inputs to compute daily exchange rate predictions based on the idea the IFE and PPP relations are viable models to predict daily exchange rates. We computed daily exchange rates for the entire period using this method. Deflation occurs when the inflation rate falls below $0 \%$ (a negative inflation rate). 


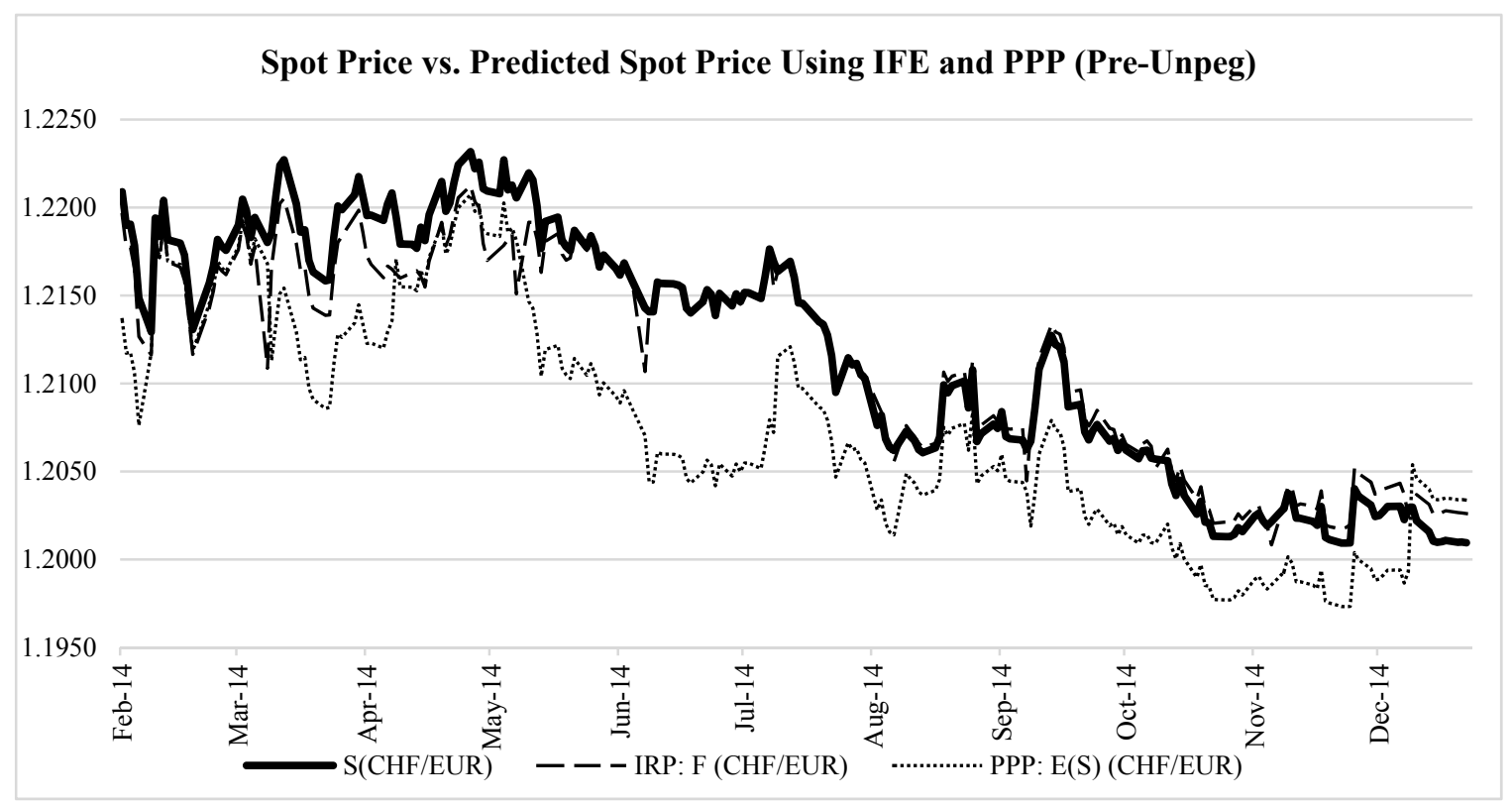

Figure 5. Panel A: Pre-Unpegged Period: Actual spot price plotted against predicted spot prices based on the prior day

Note: Libor rate and inflation rate differential for the period after unpegging of the CHF by the SNB (1/16/2014 2/24//2015).

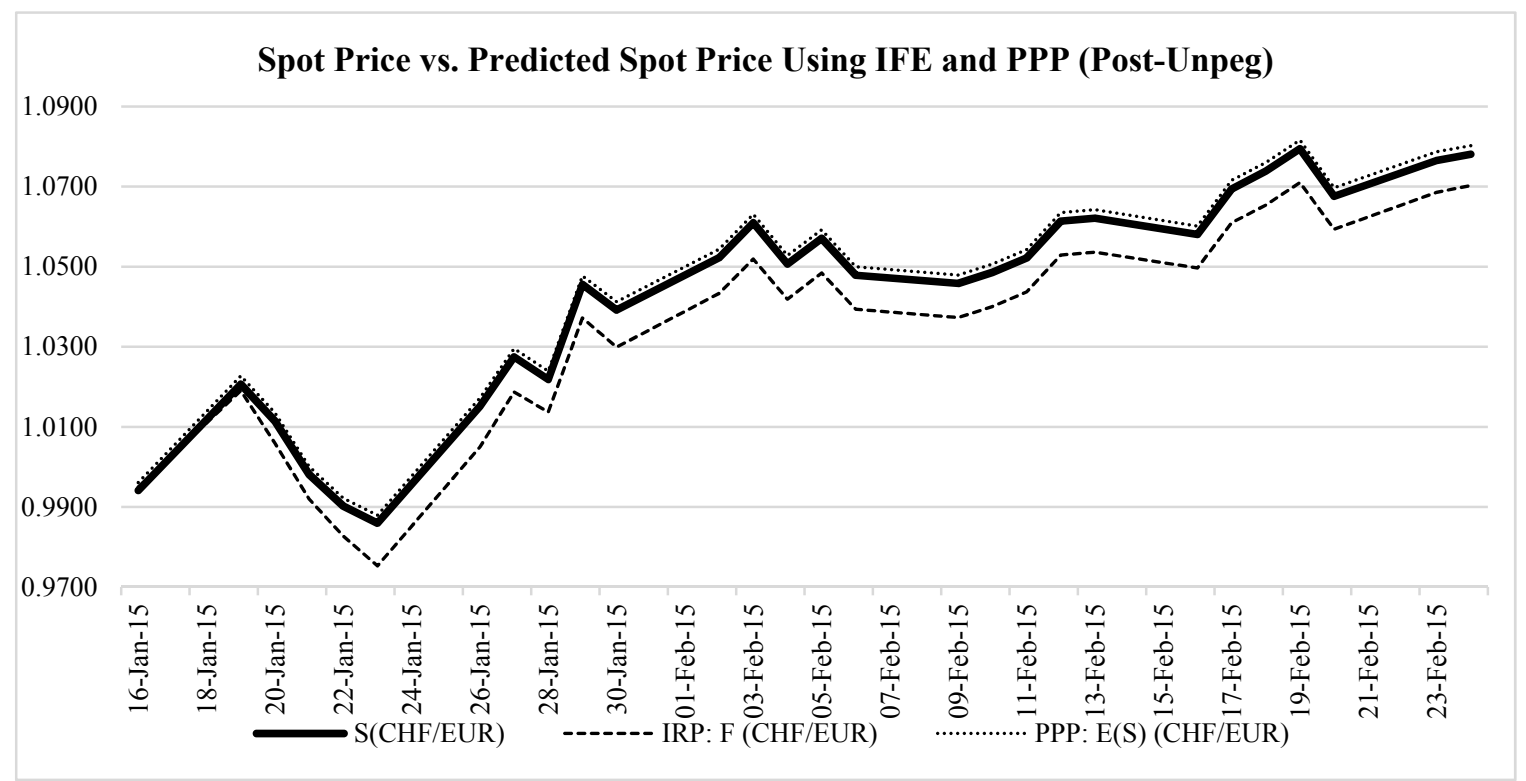

Figure 5. Panel B: Post-Unpegged Period: Actual spot price plotted against predicted spot prices based on the prior day

Note: Libor rate and inflation rate differential for the period after unpegging of the CHF by the SNB (1/16/2014 $2 / 24 / / 2015)$

Table 1 suggests that after the Swiss franc unpeg day of January 15, 2015, the actual CHF/euro exchange rate slightly increased from CHP 0.976/euro to CHP 1.078/euro (February 24, 2015). Thus it seems that during this short period of 1/15/2015-2/24/2015, the value of euro appreciated while the value of Swiss franc depreciated. At least, in the short term slightly over one month, SNB's decision of unpeg turned out to be effective, at least in terms of 
making Swiss franc value depreciating, helping Switzerland export business sectors. In the meantime, European Central bank (ECB)'s announcement of quantitative easing (QE) on January 20, 2015 was long expected by investors in the foreign exchange market, and so while the effect of QE is inherently long term, its short-term effect on euro is relatively not that substantial.

Based only on observation, the predicted spot rates based on IFE and PPP relationships seem to move relatively in sync with the actual spot rates. To further investigate whether the movement in the daily spot rates is driven by the IFE and PPP relationships, the daily interest rate and monthly inflation rate differentials were regressed against the percent changes in actual daily spot rates. For all periods analyzed, Table 2 Panels A and B show, in the short-term, there is no statistically significant evidence to conclude that interest rate and inflation rate differential drive daily changes in spot rates during before and after unpeg period, respectively, while for the entire year combining before and after unpeg period, the coefficient on interest rate differential is significant at five percent level (Panel A) and the coefficient on inflation rate differential is not significant (Panel B). Overall $\mathrm{R}^{2}$ is also pretty low. Panel C shows that for entire period combining before and after unpeg period, the coefficients on interest rate differential is significant at the one percent level, and the coefficient on inflation differential is significant at 10 percent level. Before unpeg period, however, only the coefficient on inflation rate differential is marginally significant at ten percent level and for after unpeg period, due to small observation (only one month) problem, regression does not provide the coefficients. For the entire year, the interest rate differential is more statistically significant as a predictor of spot rates relative to inflation rate differential. Combined together, because the results in Panels A and C show statistical significance between the interest-rate differentials and the daily future spot rate, from a statistical analysis, the parity relations based on IFE can predict daily spot prices better than PPP when we combine before and after unpeg macroeconomic landscape.

Our regression results reported in Table 2 are generally supportive of the earlier findings of Kravis and Lipsey (1978) and Frenkel (1981) who find that PPP did poorly in explaining the behavior of exchange rates. Similarly, Adler and Lehman (1983) found that deviations from PPP follow a random walk, without exhibiting any tendency to revert to PPP. Abuaf and Jorion (1990) suggest that while deviations from PPP tend to be substantial in the short run, deviations from PPP appear to take about three years to be reduced in half. Abuaf and Jorion's (1990) findings, however, do not apply to our study as our focus is fairly short run, i.e., daily spot rate movement. In addition, our regression results based on IFE is consistent with previous empirical studies that while the ability of interest rate differentials is likely to support the tendency for these differentials to offset exchange rate changes (Giddy and Dufey, 1973; Aliber, 1973), the relationship between the interest rate differentials and the exchange rate differentials remains to be weak (Meese and Rogoff, 1988).

Hauner, Lee and Takizwa (2011), however, suggested that numerically (but not statistically) the PPP effect is strongest under a peg regime. Taking this idea, shifting the analysis to one that is more numerical, the relationship between the predicted spot rates based on the parity relationships and the actual spot rates was analyzed looking at the daily absolute value deviation of the two rates, predicted versus actual.

Shown in Table 3 are statistical results from the analysis. Based on these results, under the IFE relations, the predicted spot rate was on average closer to the actual spot rate before the SNB removed the Swiss currency peg against the euro. Under the PPP relations, the deviation was smaller during the period after the SNB removed the peg. Looking back at Figures 2 and 3, the results seen under the IFE relations can be attributed to the near-zero Libor rate with very little fluctuation up until the removal of the peg. The relationship between a country's currency and interest rates are interdependent on one another. During the currency peg, when the SNB actively participated in the market, Swiss franc was held, for the most part, constant against the euro, a global currency. Consequently, the central bank was able to hold interest rates constant for the duration of the peg. Market participants also had this information at their disposal, including the ECB, and conducted their daily activities based on this information. Now, with the removal of the peg and the currency now freely floating, there is once again information asymmetry, resulting in greater volatility of the Swiss franc. 
Table 2. Regressions of the Percentage Change in Daily Spot Rates on Interest Rate Differential (Panel A) or Inflation rate Differential (Panel B) or Both (Panel C)

Panel A. Regression Analysis - Daily Interest (Libor) Rate Differential vs \% Change in Daily Spot Price (IFE)

\begin{tabular}{|c|c|c|c|}
\hline Time Horizon & $\begin{array}{l}\text { Coefficient on Interest } \\
\text { Rate Differential } \\
\text { p-value (1) }\end{array}$ & t-statistic (1) & $\mathrm{R}^{2}$ Coefficient \\
\hline Before Unpeg & $\begin{array}{l}-0.061 \\
(0.225)\end{array}$ & -1.22 & 0.0066 \\
\hline After Unpeg & $\begin{array}{l}0.513 \\
(0.531)\end{array}$ & 0.64 & 0.0153 \\
\hline Entire Year & $\begin{array}{l}-0.60 \\
(0.049) * *\end{array}$ & $-1.98^{* *}$ & 0.0154 \\
\hline
\end{tabular}

Panel B. Regression Analysis - Monthly Inflation Rate Differential vs \% Change in Daily Spot Price (PPP)

\begin{tabular}{llll}
\hline & $\begin{array}{l}\text { Coefficient on Inflation } \\
\text { Rate Differential } \\
\text { p-value (2) }\end{array}$ & t-stat (2) & $\mathrm{R}^{2}$ Coefficient \\
\hline Time Horizon & 0.02 & 0.75 & 0.0025 \\
Before Unpeg & $(0.451)$ & - & - \\
After Unpeg & - & & 0.0019 \\
Entire Year & -0.189 & -0.71 & \\
\hline
\end{tabular}

Panel C: Regression Analysis - Daily Libor Rate and Monthly Libor Rate Differential vs. \% Change in Daily Spot Rate (IFE and PPP together)

\begin{tabular}{llllll}
\hline Time Horizon & $\begin{array}{l}\text { Coefficient } \\
\text { p-value (1) }\end{array}$ & $\begin{array}{l}\text { Coefficient } \\
\text { p-value (2) }\end{array}$ & t-stat (1) & t-stat(2) & $\mathrm{R}^{2}$ Coefficient \\
\hline Before Unpeg & $\begin{array}{l}-0.835 \\
(0.278)\end{array}$ & $\begin{array}{l}-0.676^{*} \\
(0.063)\end{array}$ & -1.087 & $-1.87^{*}$ & 0.0247 \\
& -0.188 & & & & \\
After Unpeg & $(0.851)$ & - & -0.190 & - & 0.0015 \\
& & & & & \\
Entire Year & $-0.923 * * *$ & $-0.596^{*}$ & & & \\
& $(0.009)$ & $(0.06115)$ & $-2.62 * * *$ & $-1.8811^{*}$ & 0.0294 \\
\hline
\end{tabular}

Note: $* * *, * *$, and $*$ indicate significance at $1 \%, 5 \%$, and $10 \%$ level, respectively.

On the other hand, the results seen under the PPP relations are more difficult to interpret. Based on observation, the inflation rate differential of the two countries is very volatile and hard to explain solely based on the PPP relations. Mathematically, the drop in average deviation of actual spot rate against predicted rate can be attributed to the fact that it is difficult to measure inflation on a daily basis. Since the inflation rate is only reported and captured monthly by Bloomberg, it is not a true indicator of the true increase/decrease in the level of prices. As a result, the daily inflation rate does not capture the actual movement in the macroeconomic variable - interest rate, since prices are sticky. Hence we conclude that it would be inadequate to predict the daily change in the expected spot rate based on inflation rate differential. However, as we suggest before, current inflation rates both in Switzerland and Euro zone are extremely low close to zero (in fact both have negative inflation rate in deflation), potential bias will be minimal. Also post the unpegging, we observe data for only thirty days, hence it is not enough data to determine the true deviations. 
Table 3. Analysis of spot rate deviation - Statistical measures examining the absolute deviation of the actual spot rate relative to predicted spot rates based on IFE and PPP relationships

\begin{tabular}{lrr}
\hline & International Fisher effect (\%) & Purchase Power Parity (\%) \\
\hline Min & 0.0000 & 0.0996 \\
\hline Max & 1.0920 & 0.8032 \\
\hline Median & 0.0683 & 0.3015 \\
\hline Average (Pre) & 0.0872 & 0.3892 \\
\hline Average (Post) & 0.7391 & 0.2008 \\
\hline Average (All) & 0.1619 & 0.3684 \\
\hline
\end{tabular}

Analysis of the absolute deviation of actual spot rates from predicted spot rates based on the international parity relationships alone doesn't indicate the ability to predict future spot rates. Especially, considering currency movement in general rarely fluctuates as dramatically as it did when the SNB removed the currency peg against the euro. Therefore, in addition to the study above, another test was conducted to evaluate the extent to which the two parity relationships can predict the daily directional movements of the daily spot rates. A summary of the results can be seen in Table 4 Panels A and B, which show the number of days in which the directional movements of the actual daily spot rate were consistent with the predicted daily rate, respectively, before and after the removal of the currency peg. The results indicate that the IFE and PPP relations can be used to explain, roughly, on average, the directional movement of the daily spot rate half the time. These results are supportive of our hypothesis 1 . From the two tests conducted, focusing on the absolute and directional deviation of the actual spot price from the predicted spot price, while the two parity relations are unable to predict exact daily movement of spot rates both statistically and numerically, both parity relations do provide directional changes reasonably well (see Figure 4 and Figure 5 Panels A and B).

Table 4 Directional change of spot rates

Panel A: Analysis of directional movement of spot rate based on IFE

\begin{tabular}{lcccr}
\hline & Pre-Unpeg ( Days) & Pre-Unpeg (\%) & Post-Unpeg (\# Days) & Post-Unpeg (\%) \\
\hline Consistent & 109 & 51.9 & 13 & 44.8 \\
\hline $\begin{array}{l}\text { Not } \\
\text { Consistent }\end{array}$ & 101 & 48.1 & 16 & 55.2 \\
\hline \multicolumn{7}{l}{ Panel B: Analysis of directional movement of spot rate based on PPP } \\
\hline \multicolumn{7}{c}{ Pre-Unpeg (Days) } & Pre-Unpeg (\%) & Post-Unpeg (\# Days) & Post-Unpeg (\%) \\
\hline Consistent & 111 & 49.3 & 13 & 44.8 \\
\hline $\begin{array}{l}\text { Not } \\
\text { Consistent }\end{array}$ & 114 & 50.7 & 16 & 55.2 \\
\hline
\end{tabular}

Note: The number of days the directional change in predicted spot rate based on IFE and PPP are consistent with the directional change in the actual spot rate

\section{Conclusion}

Based on the statistical and numerical studies conducted, in the short-term, while the international parity relations cannot predict the next day expected future spot rate precisely (CHF/EUR), they can, at least, inform the users with the trend or general direction. That being said, practically, there is still relevance in being able to forecast the general direction in which the spot rate, Swiss franc relative to the euro, moves based on the changing interest and inflation rate differentials between Switzerland and Eurozone. For investors and financial managers who are more concerned with the exchange rate trend and directional change find benefits using the two parity relations.

Another objective of the study is to understand and predict the implications of the actions taken by the SNB and ECB. Interestingly, because there is some statistical and numerical evidence from supporting the idea that the parity 
relations can be used to predict daily short-term rates, the results gathered supports a conclusion made by Hakkio (1992), who suggest in the short-term different political and economic shocks will drive the movement of exchange rates. Focusing the Swiss unpegging event happened on January 15, 2015, we find the following three empirical regularities. First, and most importantly, our empirical results based on the two parity relations of International Fisher effect (IFE) and Purchasing Power parity (PPP), suggest that future daily spot rates predicted based on the IFE relations, in general, is relatively better in forecasting the daily spot rate compared to that of the PPP relations. This finding is generally supportive of Frenkel (1979) and Hakkio (1992) in that daily short-term rates can be used to forecast future daily spot rate changes, at least in directional change, based on international parity relations. Second, the analysis of the absolute deviation of actual spot rates from predicted spot rates based on IFE seems to be lower than those from PPP. Third, the percentage of the number of days the directional change is consistent with the predicted spot rate based on IFE is slightly higher than the same percentage based on PPP. Combined together, our results suggest that consistent with our hypothesis 1 , current spot prices, especially based on IFE, can be used to predict the directional change of short-term daily exchange rate of the Swiss franc.

Moving forward, this paper adds credibility to the idea that short-term exchange rates can be looked at using the parity relations to understand the probable direction of exchange rates and the political and economic events that may impact that movement of the exchange rate of concern. In addition, our analysis suggests that while SNB's sudden decision to abandon the ceiling on the Swiss franc caught markets totally off-guard, its short term effect on Swiss franc depreciation seems to be relatively more effective than ECB's announcement of quantitative easing on euro value at least in the short term slightly over one month between January 15, 2015 and February 24, 2015 between Switzerland and euro zone. Clearly, however, this does not mean that ECB's decision is not effective. In fact, a weaker euro in comparison with relatively stronger US dollar boosts the competitiveness of eurozone exports in global trade, a way for the ECB to buoy the region's growth (Iosebashvili and Zeng, 2015).

\section{References}

Abuaf, N., \& Jorion, P. (1990). Purchasing power parity in the long run. Journal of Finance, 45, 157-174. http://dx.doi.org/10.1111/j.1540-6261.1990.tb05085.x

Adler, M., \& Lehman, B. (1983). Deviations from purchasing power parity in the long run. Journal of Finance, 45, 157-174. http://dx.doi.org/10.1111/j.1540-6261.1983.tb03835.x

Aliber, R. (1973). The interest rate parity theorem: A reinterpretation. Journal of Political Economy, 1451-1459. http://dx.doi.org/10.1086/260137

Blackstone, B., \& Maclucas, N. (2015). Swiss move roils global markets. Wall Street Journal. Retrieved from http://www.wsj.com/articles/switzerland-scraps-currency-cap-1421320531?mg=id-wsj

Chen, Y., \& Tsang, K.P. (2013). What does the yield curve tell us about exchange rate predictability? Review of Economics and Statistics, 95(1), 185-205. http://dx.doi.org/10.1162/REST_a_00231

Engel, C., \& Kenneth, D. W. (2005). Exchange rates and fundamentals. Journal of Political Economy, 113, 485-517. http://dx.doi.org/10.1086/429137

Eun, C., \& Resnick, B. (2015). International Financial Management $\left(7^{\text {th }}\right.$ ed.). McGraw-Hill Irwin Publishing Co.

European Commission Directorate-General for Trade. (2014). European Commission. Retrieved from http://ec.europa.eu/trade/policy/countries-and-regions/countries/switzerland/

Fisher, I. (1930). The Theory of Interest. New York: Macmillan.

Frenkel, J. (1979). On the Mark: A theory of floating exchange rates based on real interest differentials. American Economic Review, 69, 610-623.

Frenkel, J. (1981). Flexible exchange rates, prices and the role of news: lessons from 1970s. Journal of Political Economy, 89, 665-705. http://dx.doi.org/10.1086/260998

Frenkel, J., \& Rose, A. (1995). Empirical research on nominal exchange rate (pp. 1689-1729). In Gene Grossman and Kenneth Rogoff (Eds.), Handbook of International Economics (Vol. 3, 1995). Amsterdam: Elsevier Science.

Giddy, I., \& Dufey, G. (1975). The random behavior of flexible exchange rates. Journal of International Business Studies, 1-32. http://dx.doi.org/10.1057/palgrave.jibs.8490765

Global Competitiveness Report 2014-2015. (2015). World economic forum. Retrieved from http://reports.weforum.org/global-competitiveness-report-2014-2015/report-highlights/\#map 
Grossman, A., \& Simpson, M. W. (2009). Predictability of the U.S. dollar index using a U.S. export and import price index-based relative PPP model. Journal of Economics and Finance, 417-433.

Hakkio, C. S. (1992). Is purchasing power parity a useful guide to the dollar? Economic Review, Federal Reserve Bank of Kansas, Third Quarter, 37-51.

Hauner, D., Lee, J., \& Takizawa, H. (2010). In Which Exchange Rate Models Do Forecasters Trust? Steven Phillips. International Monetary Fund Working Paper, May, 1-17.

Iosebashvili, I., \& Zeng, M. (2015). Euro speeds near parity with dollar. Wall Street Journal, C4. March 11.

Kravis, I., \& Lipsey, R. (1978). Price behavior in the light of balance of payment theories. Journal of International Economics, 193-246. http://dx.doi.org/10.1016/0022-1996(78)90022-3

Laidi, A. (2012). Exploiting the Franc Peg. FUTURES. Retrieved from http://www.futuresmag.com/2011/12/31/exploiting-franc-peg

Madura, J. (2014). International Financial Management ( $12^{\text {th }}$ ed.). Cengage Learning.

Mark, N. C. (1995). Exchange rates and fundamentals: evidence on long-horizon prediction. American Economic Review, 85, 201-218.

Meese, R., \& Rogoff, K. (1988). Was it real? The exchange rate interest rate differential relation over the modern floating rate period. Journal of Finance, 43, 933-948. http://dx.doi.org/10.1111/j.1540-6261.1988.tb02613.x

Nelson, C. R., \& Siegel, A. (1987). Parsimonious modeling of yield curves. Journal of Business, 60, 473-489. http://dx.doi.org/10.1086/296409

Phillips, M. (2015). Absolutely everything you need to understand what happened to the Swiss franc this week. January 18 , Reuters.

Rogoff, K. S., \& Stavrakeva, V. (2008). The continuing puzzle of short horizon exchange rate forecasting. NBER working paper 14071.

Sarno, L. (2005). Viewpoint: Towards a solution to the puzzles in exchange rate economics: Where do we stand?" Canadian Journal of Economics, 38, 673-708.

Switzerland - Gross Domestic Product (GDP) Growth 2018 | Statistic. (2015). Statista. IMF. Retrieved from http://www.statista.com/statistics/263611/gross-domestic-product-gdp-growth-in-switzerland/ 